\title{
High-performance Work Practices in Europe: Challenges of Diffusion
}

\author{
Peter Totterdill, Oliver Exton, Rosemary Exton, \\ Michael Gold
}

\begin{abstract}
Although the evidence supports the role of high-performance work practices (HPWP) in underpinning improvements in organisational performance, it is striking that so few companies in Europe seem willing to introduce them. The purpose of this article is to examine the barriers to the dissemination of HPWPs, and especially the challenges and dilemmas it presents to policy makers at the design stage. The article is based on in-depth, semi-structured interviews with the principal officials responsible for seven HPWP programmes across six European countries, as well as on extensive secondary material. The interviews were analysed to identify key issues of concern and then grouped to provide general insights into the operation of HPWP programmes. The article identifies a number of challenges common to all the programmes that need resolution, including tensions between research and dissemination, whether programmes should aim at breadth or depth, and the role of the social partners. It accordingly advocates a new research agenda that focuses on policies to achieve their wider diffusion, which will be of particular value to policy-makers. It also proposes that research should be directed away from replicating studies that demonstrate the effectiveness of HPWPs and towards analyses of constraints on dissemination and the means to overcome them.
\end{abstract}

Keywords: Employee participation, Europe, high-performance work practices, organisational performance, quality of working life, Workplace Innovation, work organisation 
The key to genuinely sustainable competitive advantage, it has been argued, depends on the capacity of the organisation to learn to develop all its resources to the full (MacLeod \& Clarke 2009). Successful and sustainable organisations create workplace environments which enable employees at all levels to use their entire range of knowledge, competencies and creativity (Totterdill et al. 2002). This view looks beyond standard economistic models with their emphasis on quantifiable factors: such as machinery, investment and labour costs (Cressey 2009), to recognise the contribution of those intangible, qualitative resources and relationships that are often hard to measure, such as involvement schemes, teamwork, enhanced training and forms of profit-sharing. Such a perspective fits well within the long European tradition of seeking convergence between market-oriented policies and a healthy socio-economic environment (Kester et al. 2003).

Competitiveness is consequently viewed as the outcome of wider social processes in which work is an essential part of human life and individual identity. The term "high-performance work practices" (HPWPs) is often used to describe these processes, though "Workplace Innovation", which extends beyond work practices to cover production and operations management as well, may also be found. Indeed, a distinction may be drawn between highinvolvement work practices, such as work organisation and job design, and high-commitment employment practices, which include those forms of employment relations that enhance workers' commitment and motivation (Boxall \& Macky 2009). Terms like the "high road" approach to management and "partnership" may be used too (for a discussion of these terms, see Eurofound 2015: 15-24). In this article, we follow usage elsewhere (for example, Eurofound 2012), which uses "high-performance work practices" to cover a broad range of practices that focus on quality and efficiency at the workplace as well as various forms of voice mechanisms, notably direct and representational participation, and other appropriate management practices. Indeed, Fu et al. (2015: 211) define HPWPs broadly as "a system of HRM practices designed to enhance employees' skills, commitment and productivity in such a way that employees become a source of sustainable competitive advantage”.

Yet there is a paradox at the heart of the debate about HPWPs in Europe. On the one hand, the evidence, though nuanced, generally supports the role of these practices in underpinning improvements in organisational performance (Guest \& Peccei 2001). On the other hand, rather few companies across Europe actually seem willing to introduce these policies (Thelen 2001; Bélanger \& Edwards 2007). This article focuses on possible reasons for this reluctance, which we call the "challenges of diffusion". We begin by examining the evidence for the contribution made to performance by HPWP and outlining our research methods, before analysing the content and structure of a variety of diffusion programmes across six European countries: Belgium, Finland, France, Germany (at federal and regional levels), Ireland and Norway. We examine the nature of the challenges they all face and conclude that a new research agenda is required that centres on the constraints hindering the wider diffusion of HPWP.

\section{The contribution of HPWP to organisational performance}

Researchers have long attempted to establish a relationship between organisational performance and productivity on the one hand, and a range of human factors on the other. Huselid (1995), for example, considers over a dozen human factors, such as recruitment, job analysis and performance appraisal, as well as specifically involvement practices including information sharing and the use of employee attitude surveys. Indeed, evidence suggests that voice systems: forms of direct and representative participation practices that combine an 
emphasis on job design and quality, have the most positive effects on employee attitudes and behaviour relating to productivity, output quality and innovation (Beaumont \& Hunter 2005; Teague 2005). They create a climate of trust where individual employees are confident that their contribution will be valued (CBI-TUC 2001). Research also highlights the importance of a set of internally consistent policies and practices in ensuring that human capital contributes to the achievement of an organisation's business objectives, including compensation systems, team-based job design and employee “empowerment” (Huselid et al. 1997; Teague 2005).

Such evidence is international. Reviews of Australian, European and North American literature for the European Commission demonstrate a clear consensus regarding a positive relationship between participative forms of HPWP and performance (Savage 2001; Brödner \& Latniak 2002). One of the most significant studies, the Employee Participation and Organisational Change (EPOC) survey of 6,000 European workplaces, confirms that direct employee participation and teamworking can have strong positive impacts on both productivity and quality of products or services (European Foundation 1998). Similar results on the impact of HPWPs have been recorded in surveys from numerous individual European countries, such as Belgium (De Winne \& Sels 2010), Finland (Antila \& Ylöstalo 1999), Germany (Lay et al. 1996), Ireland (Guthrie et al. 2009), Spain (Cabello-Medina et al. 2011), Sweden (ITPS 2001) and the UK (Snape \& Redman 2010), as well as from the USA (such as Jiang et al. 2012).

Studies suggest that HPWPs contribute to higher performance in a variety of ways, for example by strengthening the relationships between employers carrying out distinct functions in settings that require interdependence (Gittell et al. 2010); reducing turnover rates and improving customer service (Batt \& Colvin 2011); and by helping new ventures to develop into sustainable businesses through sales growth and innovation (Messersmith \& Guthrie 2010).

However, some researchers have found little effect of HPWPs on labour efficiency (Cappelli \& Neumark 2001), while others conclude that moderate levels of HPWPs may be more effective than higher levels, which are associated with greater stress (Godard 2001). Examples of "partnership" between employers and unions may prove fragile because of competitive labour markets and the threat of redundancies, while in other cases employees may actually prefer adversarial unions because they exert greater influence over pay and conditions than those that are more pro-partnership (Danford et al. 2005). Other researchers criticise HPWPs on the grounds that they may lead to greater stress and work intensification (Ramsay et al. 2000; Kelly 2004), while yet others have highlighted the methodological and conceptual dilemmas that these attempts entail (Purcell \& Kinnie 2010).

Certain organisational theorists therefore argue that the value of general concepts, theories and methods in achieving HPWP objectives is rather limited (Garibaldo \& Belussi 1996). Members of an organisation have to create their own future by developing "local theories" to fit local circumstances. In other words, it is necessary to develop HPWPs that create hybrids (Latour 1993), drawing on external experience but customising and improving it through local knowledge, resources, cultures and institutions. The result is a complex body of knowledge that requires careful interpretation. Boxall and Macky (2009: 17) consequently argue that the current state of knowledge on HPWPs:

... implies that there are possibilities for win-win outcomes in certain contexts but not without careful management of inherent tensions for both parties [managers and employees]. 
Context here might refer to a variety of factors, including the size of the organization involved, the skills level of its workforce, the nature of its product market, the consistency amongst the set of HR practices that it operates, the technologies that it uses and its business strategy, all of which create the conditions for different styles of HRM, high road or low road. For example, a company competing in the information and communications sector, reliant on a high-skilled, flexible workforce, is more likely to pursue high-road HRM strategies than one employing predominantly semi-skilled part-time workers in a canning factory. Cumulatively, then, the research demonstrates that a positive relationship between HPWPs and improved performance does exist, though it is not simple. The impact of people on performance is mediated by a wide range of contextual factors: in short, every case is different.

\section{Overcoming obstacles: the need for public policy intervention}

Successive studies have made it clear that the spread of HPWP in Europe is limited. This can be explained by a number of mutually reinforcing factors (Totterdill et al. 2002) including: low levels of awareness of innovative practice and its benefits amongst managers, social partners and business support organisations; poor access to evidence-based methods and resources to support organisational learning and innovation; uneven provision across Europe of knowledge-based business services and other publicly provided forms of support; and the failure of vocational education and training to provide knowledge and skills relevant to new forms of work organisation.

A European Commission study (Business Decisions Ltd, 2000) demonstrated that targeted public programmes in some EU countries had begun to address these constraints. Such programmes typically include: accumulating, analysing and distributing knowledge of leading-edge practice and evidence-based approaches to change; establishing closer links between researchers and practitioners; action research to promote workplace innovation; developing new learning resources to support workplace change; providing knowledge-based business support; and creating inter-company learning networks.

The practical challenge for policymakers is multidimensional. The task is less to discover "what works": for which evidence, as noted above, is available, but rather to discover how to resource and support sustainable HPWPs on a large scale. In this respect, the policy response across Europe has been uneven. In France, Germany and some Nordic countries, for example, the provision of support for Workplace Innovation has been a constant though evolving feature of the policy landscape for more than 30 years. Elsewhere in Europe, however, such support has been either occasional or non-existent, though in the light of the literature on "varieties of capitalism" (Hall and Soskice 2001), this observation should not be surprising.

It is in line with Godard's (2004) assessment that constraints on the development of HPWPs are likely to be greater in liberal market economies (LMEs), such as Ireland and the UK, than in the co-ordinated market economies (CMEs) of northern Europe. Adopting what he calls a "political economy" approach, Godard argues that HPWPs reflect challenges affecting the LME paradigm in which distrust and commitment problems underpin the employment relationship to a greater extent than in the CME paradigm. This might suggest that programmes designed to advance HPWPs will be more successful in CMEs than in LMEs, as levels of trust are already higher. That is, managers in organisations based in CMEs may be more likely to perceive HPWPs as "opportunities" rather than as "threats" as they fit more snugly within their existing high-trust employment relations systems. By contrast, managers in organisations based in LMEs may be more likely to perceive them as "threats", ready to 
challenge or even undermine familiar top-down management structures, and so may be more likely to reject them. As Kennedy and Fiss (2009: 900) put it:

Framing adoption decisions as either opportunities or threats thus affects whether, when, and to what extent organisations adopt diffusing innovations in technology or administrative practice.

This article analyses the role of HPWP programmes across six European countries, four of which: Belgium, Finland, Germany and Norway, may be regarded as CMEs, with France as a hybrid (Kang \& Moon, 2012) and Ireland at the time as a "reforming" LME on account of its national social partnership framework that, before its collapse in 2009, covered pay, taxation, social welfare, education and health (Casey \& Gold 2000). These countries appeared to provide the most auspicious terrain for the growth of HPWP given their generally collaborative industrial relations systems, with France and Ireland as outliers. The programmes themselves were all designed to diffuse HPWPs as widely as possible across their territories. The actors concerned have to generate strategies to formulate new rules and practices, transform existing systems and seek co-operation from other organisations and social groups within a "variety of capitalism" that generally supports their activities. Nevertheless, our analysis uncovers a range of challenges or dilemmas that policy-makers need to grapple with in even the most supportive circumstances in CMEs. In this article, we accordingly focus on the constraints that actors confront as they attempt to deal with the challenges raised in diffusing HPWPs.

\section{Methods}

We had no a priori assumptions about the nature of "good" policy based on national experience. Our approach, rather, was inductive and interpretive in that we sought to gain insight into participants' understanding of: the nature of Workplace Innovation; its policy significance; why intervention is necessary; the factors that underpin successful policy design and implementation; the significance of partnerships with unions, employers' organisations and universities; and, above all, the challenges involved in diffusing the practice of Workplace Innovation.

Each of the cases included in the study represented between one and four decades' operational experience. We omitted the well-known Swedish Working Life Programme because it had been abandoned in 1995, and the Swedish Working Life Institute itself closed down in 2007. We also excluded countries like Denmark and the Netherlands because their support for HPWPs comes through indirect policy measures, such as programmes designed to promote healthy working or competitiveness, rather than workplace innovation per se. A programme launched in 2014 in the Basque country in Spain, designed to promote a "socially responsible Territory", was excluded simply because there was still little to report. To our knowledge, there are no other operational national or regional-level programmes in Europe.

The EU-funded Work-in-Net project had collected basic data on the structure and organisation of the programmes in each country in 2005 (Zettel 2005). When we embarked on this research in 2009, our first step was to analyse this information, invite the officials responsible for each programmes to update it and to supply us with any relevant new material, which we checked against existing literature on HPWP. We subsequently carried out 18 
interviews with these officials and other colleagues to discuss specific themes in greater depth. Interviews, which were not recorded, typically lasted around three hours and were conducted in English, which presented no problems. The interview schedule was semistructured to give participants the opportunity to raise issues that we had not anticipated. The result was a UKWON report published in 2009 (Totterdill et al. 2009), which we used as a basis for this current article.

\begin{tabular}{|c|c|c|}
\hline Programme & Interviewees & Number \\
\hline Belgium: Flanders Synergy & $\begin{array}{ll}\text { Director, } & \text { Programme } \\
\text { Manager } & \end{array}$ & 2 \\
\hline France: ANACT & $\begin{array}{l}\text { Director of } \text { International } \\
\text { Relations, two Programme } \\
\text { Managers }\end{array}$ & 3 \\
\hline Finland: TEKES & $\begin{array}{l}\text { Programme } \\
\text { Principal Research Officer, } \\
\text { Programme Manager }\end{array}$ & 3 \\
\hline $\begin{array}{l}\text { Germany: Federal Ministry } \\
\text { of Education and Research }\end{array}$ & $\begin{array}{ll}\text { Programme } & \text { Director, } \\
\text { Principal Manager } & \end{array}$ & 2 \\
\hline $\begin{array}{l}\text { Germany: Work-oriented } \\
\text { Modernisation Programmes, } \\
\text { North Rhine-Westphalia }\end{array}$ & Director & 1 \\
\hline $\begin{array}{ll}\text { Ireland: } & \text { Workplace } \\
\text { Innovation Fund } & \end{array}$ & $\begin{array}{l}\text { Programme Director, } \\
\text { Programme Manager }\end{array}$ & 2 \\
\hline $\begin{array}{l}\text { Norway: VRI } \\
\text { Norwegian Research Council } \\
\text { (NRC); Work Research } \\
\text { Institute (WRI); Norwegian } \\
\text { Confederation of Trade } \\
\text { Unions (LO) }\end{array}$ & $\begin{array}{l}\text { Senior Programme Manager, } \\
\text { Programme Manager (NRC); } \\
\text { Member of VRI Programme } \\
\text { Board, Programme Architect } \\
\text { (WRI); Union Representative } \\
\text { on VRI Programme Board } \\
\text { (LO) }\end{array}$ & 5 \\
\hline Total: & & 18 \\
\hline
\end{tabular}

Tabell 1 List of interviewees by Country/Programme

In February 2015, we invited the same officials, or their replacements, to update their earlier material by means of a questionnaire (they all did so). The major change between 2009 and 2015 was that the Irish programme had come to an end in 2009, though we still include it in our analysis here because of its significance for HPWP in an LME. 


\section{A comparative framework}

\section{Case studies}

This study is not intended to provide a structural comparison of the major workplace innovation programmes in Europe but seeks rather to identify the qualitative factors that inform their rationale, design, operation and sustainability. Direct comparison of programmes is difficult because each has been designed to address challenges within a particular economic, social and political context; each sits in a different relationship with the wider policy framework; and each has followed its own evolutionary path through cycles of learning, evaluation and revision. Here we focus on the lessons, choices and challenges for programme design that can be extracted from their experience.

- In Belgium, Flanders Synergy was launched in 2009 as a membership organisation, focusing on improving the quality of working life through action research, the development of learning networks and evidence-based consulting. Funded through private and public source, its projects aim to enhance innovative working behaviour, reduce absenteeism and engage older workers in active employment. It covers around 10,000 workers in over 200 companies.

- In Finland, TYKES (the National Workplace Development Programme) was launched in 1996, merging with the National Productivity Programme in 2004. It is a research-based development programme aimed at improving productivity and quality of working life by promoting the development of human resources, innovation and the active engagement of employees in Finnish workplaces through financial support and other means. In 2008, TYKES was transferred from the Ministry of Labour to TEKES (the Finnish Funding Agency for Innovation), indicating that the policy rationale for promoting HPWP had moved from an industrial relations niche to the mainstream industrial and competitiveness policy framework (Alasoini 2011). Its current programme, "Liideri - Business, Productivity and Joy [sic] at Work" (2012-18), focuses particularly on small and medium-sized enterprises (SMEs). So far, it has benefitted some 30,000 workers across 150 companies (Alasoini 2015).

- In France, Anact (L'Agence nationale pour l'amélioration des conditions de travail) was formed in 1973 against a backdrop of industrial relations conflict, in part a result of the Tayloristic forms of work organisation that predominated in French enterprises. Anact was created as a statutory national agency, involving social partners particularly through regional economic development strategy, but funded by the state with the aim of improving health and safety and reducing conflict through the introduction of a consistent policy framework for new forms of work organisation (Anact 2012). Since 2008, Anact has run the Fund for the Improvement of Working Conditions (FACT) that provides short-term intervention in SMEs or groups of SMEs for projects adopting a comprehensive approach to improving working conditions. By 2014, 102 projects were underway, about $20 \%$ of them covering groups of SMEs. ANACT's Social Innovation Fund (FISO), established in 2013 by the President, François Hollande, offers advances to finance socially innovative projects across the French regions. Two further programmes, aimed specifically at the co-operative and social enterprise sector respectively, provide financial support for eligible projects.

- In Germany, the Federal Ministry of Education and Research has had a long tradition of national initiatives supporting the development of HPWP since the launch of the Humanisation of Working Life programme in 1974. Successive programmes have reflected changing national economic and social conditions as well as the 
evolution of policy priorities but have done so within a consistent institutional framework, allowing cumulative learning and the creation of considerable knowledge. Its current programme, "Working, Learning, Developing Competences", has run since 2007 and forms part of Federal research funding policy. It provides advice and funding for action-oriented research projects, covering so far around 2.5 million workers in 1,500 companies. Further programmes run alongside with different focuses.

- In Ireland, the Workplace Innovation Fund (WIF) was established to support collaboration and participation at enterprise level. Arising from a recommendation contained within the Government's National Workplace Strategy, WIF was delivered through Towards 2016, Ireland's last national social partnership agreement, which collapsed in 2009. WIF had been organised into three interrelated strands covering enterprise-level projects in the private sector, initiatives to strengthen the role of social partners in facilitating HPWP and a public awareness campaign to disseminate knowledge of HPWP. However, it was abolished in 2009 with the first wave of austerity cuts, along with the National Centre for Productivity and Performance. Approvals for new projects accordingly ceased, though payments for projects approved earlier are continuing, administered through Enterprise Ireland, the government organisation now responsible for the development of Irish companies (Enterprise Ireland, 2013).

- The Work-oriented Modernisation programmes in the state of North RhineWestphalia in Germany represent an important example of a regional initiative designed to achieve wide-scale dissemination of HPWP. They represent a relatively rare example of the widespread use of European Social Fund resources to support workplace innovation. Led by GIB (Gesellschaft für Innovative Beschäftigungsförderung GmbH, or Innovative Employment Promotion Company), which was set up in 1986 as an agency of the North Rhine-Westphalian regional government, there are five programmes characterised by capacity building, harnessing diverse sub-regional agencies in promoting workplace innovation and recruiting enterprises to the programme (GIB, 2012). For example, "Consulting Services for Developing SME Potential” supports short-term workplace change projects as well as longer-term development of organisational strategy. It has assisted 22,000 companies employing some 770,000 workers since its launch in the year 2000.

- The Norwegian VRI (Virkemidler for Regional FoU og Innovasjon, or Programme for Regional R\&D and Innovation), which runs from 2007 to 2016, differs from programmes in the other five countries included in this study because it treats HPWP as a possible dimension of regional development rather than as a policy objective in its own right. However, HPWP is not privileged within VRI: it appears only to the extent that the regional development coalitions which are the recipients of VRI funds wish to include it within their much wider portfolios of activity. Nonetheless VRI inherits the dialogue-based approach to workplace innovation developed in predecessor programmes from the early 1990s and offers the potential to mainstream HPWP within wider policy frameworks. A further programme, INKLUD, was launched in 2015. However, uptake overall has been limited, with only an action research project in Trøndelag region during an earlier phase of VRI and, currently, a pilot project in Rogaland region. 


\section{The challenges of diffusion}

All the programmes considered here are designed to promote partnership-oriented HPWPs, which necessarily implies experimentation and learning. Furthermore, they all share a common commitment to publication of actionable knowledge relating to the learning generated. Programme managers in all six countries insisted that a vigorous dialogue did exist with key actors, such as government representatives and social partners. Indeed, by studying countries that were CMEs, or institutionally sympathetic to HPWPs, it was possible to ensure that the wider business environments in which programmes operated were broadly conducive to implementing HPWPs. Any challenges they faced were less likely to stem from the kind of institutional constraints that might be expected in LMEs (such as the nature of labour markets, skills levels and employer hostility) but rather from other factors, possibly related to the very design of HPWP programmes themselves. We turn now to examine the nature of these challenges.

\section{How best to target limited resources?}

None of these programmes has sufficient scale to make a significant numerical impact on workplaces throughout its territorial area, facing policymakers with a dilemma: whether programmes should focus on intensive involvement in a relatively small number of workplaces in the hope that they will generate exemplary cases which can then be publicised; or whether they should spread available resources widely, offering as many enterprises as possible just a few days' support, as with Anact's “short diagnosis” or the consultation strand in North Rhine-Westphalia, that aims to create a sustained momentum for change through small amounts of pump-priming.

There is no universal solution: the answer depends largely on the wider policy framework and other sources of tangible or intangible support available to sustain workplace innovation. The German experience, for example, suggests that combining a national research programme to develop leading-edge practice with regional programmes focusing on wide dissemination can be powerful, especially when knowledge generated by the programmes informs the construction of a broader supportive policy and social partner infrastructure.

\section{Social partners as supportive bystanders or active participants?}

The engagement of trade unions and employers' organisations is a common feature of all these programmes. Social partner endorsement of key workplace policy initiatives is regarded as an essential precondition in all six countries; moreover, unions and employers play a supportive (though rarely leading) role in recruiting companies to the programmes. The overall role of the social partners in the design and implementation of the programmes is advisory rather than actively participative. In Ireland, the former New Work Organisation programme represented a rare case in which social partners were involved as knowledgeable participants in workplace change projects.

Within each programme, workplace trade union representatives are automatically consulted and involved in projects from the design stage onwards. They are seen as potential sources of knowledge and understanding about "what really works" in an organisation as well as having the power to legitimise the project amongst the wider workforce. However, the extent to 
which workplace union representatives are provided with the knowledge or competencies to act as effective participants in change by their unions or employers is often unclear.

\section{Research, consultancy or broader policy frameworks?}

European work organisation researchers consistently call for the systemic transformation of workplaces through HPWP that focus on sustained innovation rather than target-driven programme approaches (European Foundation 1998; Totterdill et al. 2002; Teague 2005). Indeed, historically through to the present day, several programmes such as those in France, Germany and Norway have been directly or indirectly influenced by socio-technical systems theory, which emphasises the need for system-wide change rather than partial or ad hoc initiatives. Moreover, HPWP emphasises approaches to work organisation that achieve convergence between high levels of organisational performance and a high quality of working life (European Foundation 1998; Totterdill et al. 2002).

However, it is unlikely that many workplace projects across the various programmes have led to systemic change. Long-term involvement with individual workplaces is more characteristic of the research-oriented programmes, which are necessarily limited to cases with the potential to generate new knowledge. Other programmes provide short diagnoses of organisational practice, which are sometimes followed up with a limited number of subsidised consultancy days: the gains from these interventions can be tangible and worthwhile, but the company itself would need to drive a more holistic transformation beyond the project period (as in the Finnish programme, which provides continuing opportunities for knowledge sharing and peer support).

Public programmes are also liable to be strongly influenced by politics and by broader policy priorities. In France, for example, the Anact network prioritises actions which reflect national policy goals relating to issues such as musculoskeletal disorders, stress and ageing. On the one hand, focusing on such topical issues may provide a more effective means of seizing a company's attention than preaching the virtues of systemic transformation. On the other hand, there is the danger that a continuous refocusing on transient issues may distract from the need for systemic transformation of work processes.

\section{Niche policy or mainstream policy?}

Programmes may be successful in meeting their own targets but remain relatively unknown amongst actors in wider public policy. In the case of innovation policy, for example, support for the creation of new prototypes or products, or for the introduction of new technological systems, often neglects the social and organisational processes involved in their effective use. This lack of organisational or anthropocentric perspective can generate obstacles throughout the development and implementation stages and may result in failure to realise the full potential of technological innovation (Brödner 2002).

Likewise, regional development strategies in much of Europe attempt to tackle issues of employment and competitiveness through labour market, management development and infrastructure projects without opening the "black box" of the workplace, thereby ignoring the organisational factors which lead to job creation and business success (Fricke \& Totterdill 2004; Totterdill \& Hague 2004). Enterprises themselves and the social partners often regard work organisation as the private concern of the stakeholders in the individual workplace and 
not an obvious issue for public intervention. The incorporation of the Norwegian VC2010 programme into VRI and the Finnish Workplace Development Programme into TEKES can, therefore, be seen as an attempt to mainstream workplace innovation within the wider policy framework, taking them both out of the traditional industrial relations sphere and potentially increasing their profile and impact.

\section{What about the services sector?}

A further concern about content relates to the sectoral focus. The evaluation of the Norwegian VC2010 programme (Technopolis 2005) criticised its apparent inability to break out of a traditional manufacturing-based paradigm of work organisation; in short it failed to address the needs of the emerging knowledge-based service industries and their employees on which regional and national economic development increasingly depend.

Indeed, much of the current European literature on work organisation continues to rely on iconic examples of work organisation in manufacturing between the 1950s and the 1980s that have profoundly shaped the understanding of older generation researchers and practitioners. Europe's dependence on manufacturing is declining, yet examples of innovation in services to rival the experiences of Philips or Volvo in manufacturing have been slow to emerge (Harley et al. 2007). Underlying concepts, such as teamworking and high-involvement innovation, may be transferable between sectors but they are manifested in quite different ways and may require different vocabularies.

\section{Potential for change}

Having so far outlined the most serious constraints affecting the wider spread of HPWP programmes, we now turn to consider some of the ways in which they have, in recent years, refocused to become more efficient in diffusing results. In each case, programmes have developed more inclusive framing strategies designed to broaden their appeal through integrating the social partners, encouraging networks, and building relationships and capacity.

\section{Experts or social dialogue?}

Some researchers have argued that the design approach, with its strong reliance on expert power, has become a hindrance rather than a stimulant to real organisational change (Fricke 1997). Similarly, qualitative studies demonstrate that expert-led change is often partial, fragmented and unsustainable (Business Decisions Ltd 2000; Engeström 1992). European programmes have accordingly generally abandoned prescriptive, design-led approaches to the implementation of new forms of work organisation. All the programmes discussed here are grounded in discursive approaches to workplace innovation, typically employing explicit references to dialogue, workplace social partnership and practices that recognise the value of the tacit knowledge of frontline employees. Work-in-Net (2012) has begun to benchmark some aspects of the methods used by European workplace innovation programmes (Alasoini et al. 2004). Further benchmarking of change processes deployed in these programmes would greatly help to promote shared learning between policy designers and managers. 


\section{Casework or network?}

Similarly, programmes have refocused from case work policy models towards networking strategies. Traditional business support models in many parts of Europe have focused on subsidies to individual companies to enable them to buy in external expertise in the form of consultancy. The programme manager is often little more than an administrator, with little direct involvement in content. In recent years, however, the limitations of such casework models have become increasingly apparent, including the need to capture knowledge generated by projects effectively, the need to achieve an impact which goes beyond the casework companies themselves, and the quality of learning and innovation that takes place within change projects.

Developments in innovation theory accordingly identify the ability of inter-organisational networks to stimulate and inform change (Bessant \& Tsekouras 2001), which can be a valuable tool for policymakers seeking to promote workplace innovation (Ramstad 2009). Learning networks involving interaction between organisations can stimulate real innovation, rather than emulation, through shared reflection and peer support for learning and experimentation (Bessant \& Tsekouras 2001). For example, the ED2000 (Enterprise Development) and VC2010 programmes in Norway created collaborative networks between enterprises as a means of stimulating and resourcing incremental organisational innovations, often collectively reformulating models such as total quality management in ways that reflected the specific context and giving ownership to local actors (Gustavsen 2004). Network approaches also offer the potential to create wider ripple effects, so that intervention in one workplace can provide both the momentum and the knowledge required to stimulate wider change. Anact's "Collective Action” strand, for example, involves ten companies receiving intensive consultancy support to address a certain topic that they then share with all the others that have been recruited into the same theme-based network. Anact's approach is a potentially valuable way of maximising return on its expenditure, though the actual gains for the companies in each network are rarely evaluated.

\section{Is anybody listening?}

Dissemination strategies - notably the publication of reports and case studies - are necessary but not sufficient. Capturing the learning created by projects creates a knowledge resource but this converts into actionable knowledge only when opportunities are created for dialogue (Seely Brown \& Duguid 2000). Some programmes place great emphasis on the creation of relationship-based networks involving extensive face-to-face contact. Such relationship building is particularly notable in the case of North Rhine-Westphalia where the programme management organisation, GIB, is at the heart of a close network of sub-regional development agencies and organisations, enabling it to achieve far higher profile and penetration within the business community.

The Finnish, German Federal and Norwegian programmes all include explicit commitments to capacity building within the wider public infrastructure. Broadly, this means allocating resources to engage research institutes and universities, other public policy agencies and social partners in collaborative workplace innovation projects: an issue that might otherwise be outside their normal range of activity. This polycentric model is one in which new useful knowledge is seen to be generated through dialogue between various innovation centres in society rather than by "trickling" information from "the top down" or from "the core" to "the periphery” (Fricke 1997). 


\section{Conclusions}

The HPWP programmes analysed in this article all attempt to improve workplace practices through dissemination of best case examples. However, their attempts are hindered by a number of constraints that are arguably intrinsic to the nature of such programmes. These include the most efficient ways to target resources; integrating social partner input; balancing research, consultancy and broader policy objectives; selecting niche or mainstream policy; and sectoral focus. However, in some cases, programmes have gained success by "reframing" their strategies to appeal to wider audiences, through greater integration of social partners and improved networking. These strategies help to improve adoption motivations by encouraging policy makers to regard them as opportunities: "interpreting issues as opportunities enhances the potential for taking action, thus making organizational change more likely" (Kennedy and Fiss 2009: 900).

In the six countries studied, the modernisation of work organisation as a public policy objective is widely accepted across the mainstream political spectrum. Across Europe as a whole, however, it is not, with governments in many EU member states still regarding the organisation of work as a private matter for employers. Likewise, the European Commission's failure to take effective action in the decade after the much-heralded Partnership for a New Organisation of Work Green Paper, or in its EU2020 strategy, demonstrates a continuing lack of policy leadership. This is despite evidence of the impact of work organisation on key policy priorities such as productivity, workplace health, employability and active ageing.

The experiences of Anact and GIB in providing relatively low levels of support to a wide range of companies appear encouraging. Yet these programmes must, in part, be understood in the context of the wider policy and business environment. We would argue that the success of short-term interventions depends on the dense interaction, or "thick soup", of knowledge and culture conducive to workplace innovation, generally more prevalent in CMEs than LMEs.

The establishment of enterprise learning networks as a means of both stimulating and sustaining change is increasingly recognised, but their potential is still underexploited by most programmes. This is a key lesson. Indeed, evidence suggests that, when clusters of enterprises work together, this proves cost effective for programme agencies and is likely to deliver sustainable results. Programmes that exist in isolation may not generate enough support to secure their own future. Each programme discussed here has, in its own way, made an impact on the wider policy and institutional environment, by building trust-based collaborative networks with other agencies and actors, or by integrating with the policy mainstream.

Social partner engagement also underpins the programmes described here. This has several practical advantages for programme management and creates an industrial relations climate conducive to workplace innovation, though questions remain about its quality. Investment in the competence and capacity of social partner organisations to support and engage in workplace innovation initiatives should be an important dimension of public programmes.

It is striking that all but the Irish programme appear to have succeeded in building a robust political consensus within their national or regional context. In France, for example, there is a broad consensus between left and right concerning the value of Anact, embedded in a political culture which recognises the importance of the quality of working life. However, there is no room for complacency. While the Conservative government's abolition of the Work Research Unit in the UK under Thatcher was in line with its deregulatory labour market policies, it was more surprising that the centre-right government in Sweden should have abolished the country's renowned National Institute for Working Life in 2007. There is an important lesson 
here for policymakers and programme designers concerned with sustainability, namely, that the political dimension within the LME/CME context remains important and should not be taken for granted.

Indeed, by analysing countries that were CMEs, or institutionally sympathetic to HPWPs, we tried to hold constant the wider business environment in which programmes operated. We reasoned that any challenges they faced would then stem from the very design of the programmes themselves rather than from the kind of institutional constraints associated with LMEs, such as the nature of labour markets, skills levels and employer hostility. This rather proved the case. Hence, given the proven benefits of HPWPs, we conclude that a new research agenda is required in this area, one that, first, examines in greater depth the challenges outlined in this article to clarify the options involved in different programme designs, and, second, analyses the constraints on their wider diffusion and adoption with reference to the differences between varieties of capitalism. Only then will organisations across Europe stand a chance of tapping the opportunities for sustained innovation that their employees could generate.

\section{Acknowledgements}

We should like to thank Peter Cressey for valuable comments on an earlier draft of this article and Dimitra Gkiontsi for help in updating the findings. 


\section{References}

Alasoini T. (2011), "Workplace development as part of broad-based innovation policy: exploiting and exploring three types of knowledge", Nordic Journal of Working Life Studies, Vol.1 No.1, pp.23-43.

Alasoini T. (2015), “Two decades of programme-based promotion of workplace innovation in Finland: Past experiences and future challenges”, European Journal of Workplace Innovation, Vol.1 No.1, pp.37-54.

Alasoini T., Hanhike T. \& Ramstad E. (2004), "Benchmarking of different R and D approaches in different workplace contexts: dialogical development methods”, Work-in-Net, Bonn/Helsinki.

Alasoini T., Ramstad E., Hanhike T. \& Rouhiainen N. (2008), "Learning across boundaries. Workplace development strategies of Singapore, Flanders and Ireland in comparison”, Workin-Net, available at: www.workinnet.org/dateien/WIN_Task_5.3.pdf (accessed 19 February 2016).

Anact (2012), Homepage, available at: www.anact.fr (accessed 19 February 2016).

Antila J. \& Ylöstalo P. (1999), Functional Flexibility and Workplace Success in Finland, Ministry of Labour, Helsinki.

Batt R. \& Colvin A. (2011), “An employment systems approach to turnover: human resources practices, quits, dismissals, and performance”, Academy of Management Journal, Vol.54 No.4, pp.695-717.

Beaumont P. \& Hunter L.C. (2005), Making Consultation Work: The Importance of Process, CIPD, London.

Bélanger J. \& Edwards P. (2007), “The conditions promoting compromise in the workplace”, British Journal of Industrial Relations, Vol.45 No.4, pp.713-734.

Bessant J. \& Tsekouras, G. (2001), “Developing learning networks”, AI and Society, Vol.15 Nos.1-2, pp.82-9.

Boxall P. \& Macky, K. (2009), "Research and theory on high-performance work systems: progressing the high-involvement stream", Human Resource Management Journal, Vol.19 No.1, pp.3-23.

Brödner P. (2002), Software is Orgware - A Semiotic Perspective on Computer Artifacts, Institute for Work and Technology, Gelsenkirchen, Germany.

Brödner P. \& Latniak E. (2002), "Sources of innovation and competitiveness: national programmes supporting the development of work organisation”, Final Report to DG Employment and Social Affairs, Institute for Work and Technology, Gelsenkirchen, Germany.

Business Decisions Ltd (2000), "New forms of work organisation: the obstacles to wider diffusion", KE-47-02-115-EN-C, DG Employment and Social Affairs, European Commission, Brussels.

Cabello-Medina C., López-Cabrales Á. \& Valle-Cabrera R. (2011), "Leveraging the innovative performance of human capital through HRM and social capital in Spanish firms", International Journal of Human Resource Management, Vol.22 No.4, pp. 807-828. 
Cappelli P. and Neumark D. (2001), “Do 'high performance' work practices improve establishment-level outcomes?”, Industrial and Labor Relations Review, Vol.54 No.4, pp.737-75.

Casey B. \& Gold M. (2000) Social Partnership and Economic Performance. The Case of Europe, Edward Elgar, Cheltenham.

CBI/TUC (2001), "The UK Productivity Challenge. Report of the Best Practice and Productivity Working Party”, Confederation of British Industry/Trades Union Congress, London.

Cressey P. (2009), "The concept of resilience: its components and relevance. A theoretical and empirical analysis”, UKWON Research Paper, UKWON, Nottingham, available at: www.ukwon.net/resource.php?resource_id=261 (accessed 20 December 2012).

Danford A., Richardson M., Stewart P., Tailby S. \& Upchurch, M. (2005), Partnership and the High Performance Workplace: Workplace Employment Relations in the Aerospace Industry, Basingstoke, Palgrave Macmillan.

De Winne S. \& Sels L. (2010), "Interrelationships between human capital, HRM and innovation in Belgian start-ups aiming at an innovation strategy", International Journal of Human Resource Management, Vol.21 No.11, pp.1863-1883.

Engeström Y. (1992), "Interactive expertise: studies in distributed working intelligence”, Research Bulletin 83, University of Helsinki, Helsinki.

Enterprise Ireland (2013). Driving Enterprise, Delivering Jobs. Strategy to 2016, Enterprise Ireland, Dublin, available at: https://enterprise-ireland.com/en/Publications/ReportsPublished-Strategies/Strategy-to-2016.pdf (accessed 19 February 2016).

European Foundation for the Improvement of Living and Working Conditions (1998), New forms of Work Organisation. Can Europe Realise its Potential? Results of a Survey on Direct Participation in Europe, European Foundation, Dublin.

Eurofound (2012), Cox A., Rickard C. \& Tamkin P., Work Organisation and Innovation, Publications Office of the European Union.

Eurofound (2015), Workplace Innovation in European Companies, Draft Final Overview Report: Workplace Innovation among Companies partaking in the European Company Survey 2013: A Case Study Research, March, Dublin.

Fricke W. (1997), "Evaluation of the German work and technology programme from an action research point of view", in Alasoini T., Kyllönen K. \& Kasvio A. (Eds), Workplace Innovation: A Way of Promoting Competitiveness, Welfare and Employment, National Workplace Development Programme, Helsinki, pp.91-103.

Fricke W. \& Totterdill P. (2004), "Introduction”, in Fricke W. \& Totterdill P. (Eds), Action Research in Workplace Innovation and Regional Development, John Benjamins, Amsterdam, pp.1-11.

Fu N., Flood P., Bosak J., Morris T. \& O’Regan, P. (2015), "How do high performance work systems influence organizational innovation in professional service firms?", Employee Relations, Vol.37 No.2, pp.209-231.

Garibaldo F. \& Belussi F. (1996), "Variety of pattern of the post-Fordist economy: why are the 'old times' still with us and the 'new times' yet to come?”, Futures, Vol.28 No.2, pp.153171. 
GIB (2012), Homepage, available at: www.gib.nrw.de (accessed 19 February 2016).

Gittell J.H., Seidner, R. \& Wimbush J. (2010), “A relational model of how high-performance work systems work”, Organization Science, Vol.21 No.2, pp. 490-506.

Godard, J. (2001), "High performance and the transformation of work? The implications of alternative work practices for the experience and outcomes of work", Industrial and Labor Relations Review, Vol.54 No.4, pp.776-805.

Godard J. (2004), “A critical assessment of the high-performance paradigm”, British Journal of Industrial Relations, Vol.42 No.2, pp.349-78.

Guest D. \& Peccei R. (2001), "Partnership at work: mutuality and the balance of advantage”, British Journal of Industrial Relations, Vo.39 No.2, pp.207-236.

Gustavsen B. (2004), "Participation and local organisation”, in Fricke, W. \& Totterdill, P. (Eds), Action Research in Workplace Innovation and Regional Development, John Benjamins, Amsterdam.

Guthrie J., Flood P., Liu W., \& MacCurtain, S. (2009), "High performance work systems in Ireland: human resource and organizational outcomes", International Journal of Human Resource Management, Vol.20 No.1, pp.112-125.

Hall P.A. \& Soskice D.W. (Eds) (2001), Varieties of Capitalism: the Institutional Foundations of Comparative Advantage, OUP, Oxford.

Harley B., Allen B. \& Sargent L. (2007), "High performance work systems and employee experience of work in the service sector: the case of aged care”, British Journal of Industrial Relations, Vol.45, No.3, pp.607-633.

Huselid M.A. (1995), "The impact of human resource management practices on turnover, productivity, and corporate financial performance”, Academy of Management Journal, Vol.38 No.3, pp.635-72.

Huselid M. A., Jackson S. E.\& Schuler R. S. (1997), “Technical and strategic human resource management effectiveness as determinants of firm performance", Academy of Management Journal, Vol.40 No.1, pp.171-188.

ITPS (2001), "Enterprises in transition: learning strategies for increased competitiveness", working paper ITPS A 2001:001, Institutet för Tillväxtpolitisker Studier (Swedish Institute for Growth Policy Studies), Östersund, Sweden.

Jiang K., Lepak D.P., Hu J. \& Baer J.C. (2012), "How does human resource management influence organizational outcomes? A meta-analytic investigation of mediating mechanisms”, Academy of Management Journal, Vol.55 No.6, pp.1264-1294.

Kang N. \& Moon J. (2012), "Institutional complementarity between corporate governance and corporate social responsibility: a comparative institutional analysis of three capitalisms”, Socio-Economic Review, Vol.10 No.1, pp.85-108.

Kennedy M.T. \& Fiss P.C. (2009), "Institutionalization, framing and diffusion: the logic of TQM adoption and implementation decisions among US hospitals”, Academy of Management Journal, Vol.52 No.5, pp.897-918.

Kester G., Zammit E. \& Gold M. (2003), "Introduction: new frontiers of democratic participation at work", in Gold, M. New Frontiers of Democratic Participation at Work, Ashgate, Aldershot, pp.1-25.

Kelly J. (2004), "Social partnership agreements in Britain: labor cooperation and compliance” Industrial Relations, Vol.43 No.1, pp.267-292. 
Latour B. (1993), We Have Never Been Modern, Harvard University Press, Cambridge, Mass.

Lay G., Dreher C. \& Kinkel S. (1996), Neue Produktionskonzepte leisten einen Beitrag zur Sicherung des Standorts Deutschland. ISI Produktionsinnovationserhebung Nr. 1, Fraunhofer-Institut für System- und Innovationsfoxrschung (ISI), Karlsruhe, Germany.

MacLeod D. \& Clarke N. (2009), Engaging for Success: Enhancing Performance through Employee Engagement, Department of Business, Innovation and Skills, London, available at: http://www.bis.gov.uk/files/file52215.pdf (accessed 19 February 2016).

Messersmith J.G. \& Guthrie J.P. (2010), "High performance work systems in emergent organizations: implications for firm performance”, Human Resource Management, Vol.49 No.2, pp.241-264.

Purcell J. \& Kinnie N. (2010), "HRM and business performance”, in Boxall P., Purcell J. \& Wright, P. (Eds) The Oxford Handbook of Human Resource Management, Oxford University Press, pp.533-51.

Ramsay H., Scholarios D. \& Harley B. (2000), "Employees and high-performance work systems: testing inside the black box”, British Journal of Industrial Relations, Vol.38 No.4, pp.501-31.

Ramstad E. (2009), "Developmental evaluation framework for innovation and learning networks", Journal of Workplace Learning, Vol.21 No.3, pp.181-197.

Savage P. (2001), "New forms of work organisation - the benefits and impact on performance", European Work Organisation Network Research Paper, European Commission, Brussels.

Seely Brown J. \& Duguid P. (2000), The Social Life of Information, Harvard Business School Press, Harvard.

Snape E. \& Redman T. (2010), "HRM practices, organizational citizenship behaviour, and performance”, Journal of Management Studies, Vol.47 No.7, pp.1219-1247.

Teague P. (2005), “What is enterprise partnership?”, Organization, Vol.12 No. 4, pp.567-589.

Technopolis (2005), "Mid-term evaluation of the VS2010 programme: A report to the Research Council of Norway”, Research Council of Norway, Oslo.

Thelen K. (2001), "Varieties of labour politics in the developed democracies", in Hall P.A. \& Soskice D. (Eds), Varieties of Capitalism, Oxford University Press, pp.71-103.

Totterdill P., Dhondt, S. \& Milsome S. (2002), "Partners at work? A report to Europe's policy makers and social partners”, The Work Institute, Nottingham, available at: www.ukwon.net/resource.php?resource_id=253 (accessed 20 December 2012).

Totterdill, P., Exton, O., Exton, R. \& Sherrin, J. (2009), "Workplace Innovation Policies in European Countries. A Report to the Korea Workplace Innovation Center, Seoul”, September, UKWON, Nottingham.

Totterdill P. \& Hague J. (2004), “Workplace innovation as regional development”, in Fricke, W. \& Totterdill, P. (Eds), Action Research in Workplace Innovation and Regional Development, John Benjamins, Amsterdam, pp.43-79.

Work-in-Net (2012), Homepage, available at: www.workinnet.org (accessed 19 February 2016).

Zettel C. (2005), “European Programmes and Activities on Work-Oriented Innovation”, Joint Secretariat of Work-in-Net, Cologne. 
About the authors:

Michael Gold

Professor of Comparative Employment Relations, Royal Holloway University of London

United Kingdom

Email:. m.gold@rhul.ac.uk

Peter Totterdill

Joint Chief Executive, UK Work Organisation Network (UKWON), Visiting Professor, Kingston University London

United Kingdom

Email: peter.totterdill@ukwon.net

Rosemary Exton

Director, UK Work Organisation Network (UKWON)

United Kingdom

Email: r.exton@bath.ac.uk

Oliver Exton

Intern, University of Cambridge

United Kingdom

Email: o.exton@hotmail.co.uk 